\title{
PASCUAL-VIVES, Francisco, Consensus-Based Interpretation of Regional Human Rights Treaties, International Studies in Human Rights, vol. 129, Leiden-Boston, Brill Nijhoff, 2019, 290 pages
}

\author{
ALEJANDRO DEL VALLE GÁLVEZ \\ Catedrático de Derecho Internacional Público \\ Universidad de Cádiz (España) \\ alejandro.delvalle@uca.es \\ https://orcid.org/0000-0003-0597-4130
}

In this monograph, Doctor Pascual Vives presents us a peculiar journey through international case law and practice with regard to the main human rights treaties, the European Convention on Human Rights (EConHR) and the American Convention on Human Rights or Pact of San José (AConHR), with their own bodies and courts of interpretation and application, mainly the European Court of Human Rights (ECtHR) and the Inter-American Court of Human Rights (IACtHR).

The title of this book by Pascual Vives places us, at the outset, before what appear to be specific questions of interpretation of certain human rights treaties. However, the concept of consensus will allow the author to give a much broader dimension to these ideas. This concept will lead him to combine key institutions and concepts of International Law in what is, in fact, a theoretical and practical exercise on the functioning and coordination problems of the entire international order and its different normative sub-sectors.

Of course, this is something complex: studies of case law and the interpretation of case law with comparative analysis are complex; even more so, those which detect concepts, interpretative theories, legal doctrines and ways of reasoning in comparative jurisprudential interpretation. And even more complex are those which, along these lines, 
carry out case law analyses of human rights treaties in comparative, universal and regional systematics.

We are truly facing the most legally sensitive and practical aspects of human rights in their interpretation by international courts, since, as Professor and ECJ Judge Gil Carlos Rodríguez Iglesias insisted, the real comparative problem of human rights is to determine the scope of the recognised rights, and to calibrate their protection according to this scope in each legal system.

In this book, Dr. Francisco Pascual Vives, Associate Professor of Public International Law at the University of Alcalá de Henares in Spain, makes a very complicated journey through treaties, case law, legal theories, basic concepts, visiting the keystones of the international legal system, human rights conventions and the main international human rights jurisdictions, the ECtHR and the IACtHR.

The journey through these circuits and forums is indeed technically complex, but Dr. Pascual carries it out with naturalness and simplicity. He equips himself with the valuable toolbox of consensus generalis, which is what gives light to the journey and allows him to deduce interesting and important conclusions, based on the existence or not of state practice that demonstrates that there is an agreement on norms, convictions or interests. This will enable human rights courts to identify the standards and laws applicable to a case.

The aim is to examine how the consensualist approach to international law has been installed in the regional human rights sub-systems, and how the ECtHR and the IACtHR use it to interpret, respectively, the EConHR and the AConHR (pp. 8-9). "In fact, our initial hypothesis is that upon invoking consensus either for undertaking an evaluative interpretation or when resorting to the national margin of appreciation to exclude the international responsibility of the State the ECtHR and the IACtHR are acting as international courts and tribunals, and they are adapting a consensualist approach to the institutional framework in which they operate", (pp 1-2).

The book thus presents a very legal, systematic, analytical and rigorous approach. In its structure, there are three rationally designed Parts.

Part I presents the general theoretical framework (consensus, sectoralisation and subsidiarity): Chapter 1, 'The Notion of Consensus in Public International Law'; Chapter 2, 'The Challenges Arising from the Specialization and Sectoralization of Public International Law;' Chapter 3, 'Subsidiarity as a General Principle in International Human Rights Law'.

Part II, which I believe to be the decisive part, discusses the Consensus method and the evolutive interpretation of treaties thanks to it, setting out the reasons that have led the ECtHR and the IACtHR to undertake an evolutionary interpretation of human rights treaties and the formulas by which this consensualist approach has been carried out in 
practice. This Part consists of Chapters 4, 'Evolutive Interpretation as a Method of Interpretation in Public International Law'; 'and 5, The Evolution of Regional Human Rights Treaties through the Notion of Consensus'. It is worth noting that the latter Chapter considers how Courts interpret cases in which three Tensions arise, which the author convincingly reflects: the tension between Sovereignty and Cooperation, between Universalism and Regionalism, and between International and Constitutional Jurisdictions.

The author devotes an extensive analysis in Part III to the other side of the consensualism coin, the interpretative technique and method of the National Margin of Appreciation, divided into Chapters 6 'Scope of the National Margin of Appreciation'; 7, 'Intrinsic Circumstances Conditioning the National Margin of Appreciation'; and 8 'Consensus as an Extrinsic Circumstance Conditioning the National Margin of Appreciation'.

The conclusions of this work, which the author modestly calls 'Final Considerations', are the tangible proof of the original research work carried out, where the main conclusions of the journey are set out, with the addition of some final ideas of great interest.

The book contains a number of valuable annexes, such as the Annex of Authors Cited and the Annex of Universal, Regional and Bilateral Treaties. But I would like to highlight the bulky Annex of Jurosprudence and Case law with cited legal cases, which reflects the immense work: it includes cases from the PCIC, the ICJ, the International Tribunal for the Law of the Sea, inter-State and investment treaty tribunals and arbitral bodies, ECtHR, European Commission on Human Rights, ECJ, Inter-American Court of Human Rights, International Criminal Court, WTO dispute settlement bodies, and other international and domestic courts and tribunals. This reflects that the analysis has not been limited to the EConHR-ECtHR and the Inter-American Court and the AConHR.

Overall, this is a highly original and courageous piece of research, both in its theoretical ambition and practical analysis. One gets the feeling that the author has carried out a heavy and rigorous work of research and analysis, and at the same time, that he moves along a delicate thread like a tightrope walker, commenting on and presenting interpretations of very different cases and in very diverse human rights contexts. Like his continuous trips from Europe to America and vice versa, with easy transit through various gateways from one court to another, from one organisation and protection system to another, to different legal contexts, with different legal, institutional and social parameters that he knows very well. It is as if a vast amount of research had been done and written beforehand, and here in this book only the conclusions of the jurisprudential analysis of cases or lines of jurisprudence are presented.

In reality, the book reflects a solid line of research developed by the author over many years, and reflected in works published in journals such as the Anuario Español de Derecho Internacional or the Revista Española de Derecho Internacional. It also reflects his good command of the core issues of international law, and how he handles the key 
pieces of the legal system, analysing how they interwoven into the essential issues of international law today.

Thus, the study is crossed by issues such as the Sovereignty/Protection of Human Rights Dialectic and the ascending role of this protection in international normative and judicial venues. It also deals with the now classic problem posed by international jurisdictions to the unity of the international legal order, and sheds interesting light on how traditional categories of international law can defuse the dangers of sectorialisation, in a welcome updating of these problems.

The work has the freshness to tackle these varied and novel issues, but from a solid knowledge of the doctrinal classics on international legal structures, institutions and concepts, and with a vast knowledge of the case law and jurisprudence of human rights courts and bodies.

This systematic and rational analysis leads him to interesting approaches to crossfertilisation beyond the European legal spheres. His main contribution, of course, is the demonstration of Consensus as an essential element used by the Courts to determine the existence, evolution and practical scope of conventional human rights norms. And how "this consensus generalis constitutes an excellent mechanism to adapt the regional human rights treaties to the contemporary social reality, respecting their object and purpose and progressively extending the spectrum of rights recognised to individuals" (p. 227), thus showing the impact of consensus on the evolution of the legal system. But alongside this, there are other very relevant contributions, such as the demonstration of the reality of the sovereign side of the consensus theory, with the national margin of appreciation, to which he devotes numerous pages and chapters.

Of particular interest to me is his warning of the dangers of judicial activism in the field of Human Rights (Human Rightism) when it is not truly based on a prior general consensus of the States with respect to the hypothesis that arises in a real case. In this sense, the practice of overstep that implies departing from consensus may be of interest for the pretensions of the evolution of international society towards equitable political terrain (a paradigmatic case presented in his opinion by the case of Atala Riffo and girls v. Chile, Judgment of 2012 by the ICJHR). But lacking the reality of consensus, this judicial practice goes beyond the borders of international law and is ultimately detrimental to the whole legal system, by opening a flaw in the relations of normative sub-sectors.

In his final thoughts, I would like to highlight the author's observation on the systemic problems that can be caused or are caused by the bulky presence in international courts of specialists in domestic law, with the correlative decrease in the number of international lawyers, of experts trained in international law. This lack of a global perspective within international jurisdictions makes it difficult to articulate normative and jurisprudential elements of intra-systemic coordination in the international order. 
A few words about the author. Francisco Pascual Vives has been a recognised specialist in certain subjects, such as human rights and foreign investment, for many years. The legislative changes in Spain regarding accreditations and competitions to university positions have meant that he has arrived at the Associate Professor tenure with more than enough recognition and merit. His extraordinary capacity for work means that what for others may be feats achieved with great energy and exhaustion, in his case seem to been achieved naturally. In short, his personal, professional and intellectual maturity is very evident in this book.

Finally, I would like to end this commentary on Francisco Pascual's book with a reference to his Academic Mentor, Carlos Jiménez Piernas, Professor and Head of the International Legal Office of the Ministry of Foreign Affairs during many years. Professor Jiménez has for decades imbued his disciples at various universities (Alicante, Alcalá, Elche) with the ideas of seriousness, rigour and self-respect in university work. He has always insisted on practical analysis, on detecting and following the process of codification of international norms, on analysing with conceptual depth the institutions of international law. This teaching and guidance has helped privileged minds such as that of Dr. Pascual Vives to find a brilliant professional university path. 